\title{
İDARİ YARGILAMA USULÜNDE YARGILAMANIN YENILENMESİ BAŞVURUSU
}

THE APPLICATION OF THE RETRIAL IN THE ADMINISTRATIVE JUDICIAL PROCEDURE

\begin{abstract}
Barış ACUN* $\cdots$
Makale Bilgi

Gönderilme: 16/03/2020

Kabul: 23/06/2020

\section{Anahtar Kelimeler}

Idari Yargl,

Olağanüstü Kanun

Yolu,

Yargilamanin

Yenilenmesi,

Özel Yargllama

Usulleri.

Özet

Yargılamanın yenilenmesi, ağır hukuki hatalara sahip bir mahkeme kararının varlığını sona erdirip yeniden yargılama yapılması suretiyle hukuki güvenlik ilkesini sağlamayı amaçlayan bir kanun yoludur. Yargılamanın yenilenmesi yolu Cumhuriyet döneminde idari yargılama usulünü düzenleyen tüm kanunlarda yer almıştır. 2577 Sayılı İdari Yargılama Usulü Kanunu'nun 53. ve 55. maddelerinde de yargılamanın yenilenmesi yolunun hukuki rejimine ilişkin hükümler yer almaktadır. Öğretide, kesinleşmiş kesinleşmemiş mahkeme kararı ayrımına dayanılarak yapılan olağan - olağanüstü kanun yolu ayrımında yargılamanın yenilenmesi, olağanüstü kanun yolu kategorisinde değerlendirilmektedir. Olağanüstü kanun yolu olarak yargılamanın yenilenmesi yoluna sadece kesin mahkeme kararlarına karşı gidilebileceği kabul edilmekte; kesinleşmemiş bir mahkeme kararına karşı olağan kanun yollarına başvuru imkânı bulunduğu için kesinleşmemiş mahkeme kararlarına karşı yapılan yargılamanın yenilenmesi başvuruları idari yargı yerlerince reddedilmektedir. Yargılamanın yenilenmesi taleplerinin esas kararı veren mahkeme tarafından karara bağlanacağına ilişkin kanun hükmü sebebiyle yenileme başvurusunun, yenilenmesi talep edilen yargılamayı yapan ve yargılamanın sonunda kararı veren mahkemeye yapılacağı kabul edilmektedir. Ancak kanun hükmünde "esas karar" ifadesinin kullanılmış olması sebebiyle idari yargı yerleri tarafindan verilmekle birlikte esas karar niteliğinde olmayan mahkeme kararlarına karşı yargılamanın yenilenmesi yoluna başvurulamayacağı kabul edilmektedir. Bu çalışmada, yargılamanın yenilenmesi yoluna başvurunun günümüzdeki hukuki rejiminin incelenmesinin ardından olağan yargılama usulünden ayrılma anlamına gelen özel yargılama usullerinin yargılamanın yenilenmesi yoluna başvuruda ortaya çıkardığı soruna dikkat çekilecektir.
\end{abstract}

\section{Article Info}

Received: $16 / 03 / 2020$ Accepted: 23/06/2020

\section{Keywords}

Administrative
Jurisdiction,
Extraordinary Legal
Remedy,
The Retrial,
Special Judicial
Procedures.

\begin{abstract}
The retrial is a legal remedy that aims to provide the principle of legal security by ending the existing court decision with serious legal errors and rehearing. All codes regulating the administrative judicial procedure in the Republican period involve the foundation of the retrial. Articles 53 and 55 of the Administrative Judicial Procedure Code No. 2577 also contain provisions regarding the legal regime of the retrial. In the doctrine, the retrial in the distinction between the ordinary and extraordinary legal remedy that is made on the basis of the decisive -indecisive court decision distinction is considered in the category of extraordinary legal remedy. It is accepted that the retrial as an extraordinary legal remedy can only be made against the decisive court decisions; since it is possible to apply for ordinary remedies against an indecisive court decision, applications for the retrial against uncertain court decisions are rejected by administrative jurisdictions.It is accepted that the application for the retrial will be made to the court that decides at the end of the trial, due to the legal provision that the requests for the retrial will be decided by the court that decides judgement on the merits. However, because the term "judgement on the merits" is used in the legal provision, it is accepted that it will not be requested for the retrial against court decisions made by administrative jurisdictions but not as "judgement on the merits". In this study, the current legal regime of the application for the retrial will be examined. Later, attention will be drawn to the problem posed by special judicial procedures - leaving the general judicial procedure- in the application for the retrial.
\end{abstract}




\section{GİRIŞ}

İdareyle birey arasında çıkan bir uyuşmazlığın yargı organı tarafından kesin olarak çözülmesi, hukuki güvenlik ve hukuki istikrar ilkesinin bir gereğidir. İdari eylem veya işlem dolayısıyla bir menfaatin veya hakkın ihlal edildiği iddiasıyla açılan davanın bir süre sonra sona ermesi gerekir. Bir uyuşmazlığı sona erdiren mahkeme kararının hatalı olma ihtimali her zaman vardır. Hatalı mahkeme kararlarının hukuk dünyasında varlıklarını devam ettirmelerine engel olan kanun yolları, Türk idari yargılama hukukunda da kabul edilmiştir. Mahkeme kararının olağan kanun yollarından geçmesi kararın bir kez de başka bir yargı mercii tarafından incelenmesi anlamına gelir. Mahkeme kararının olağan kanun yollarından geçmesinin hukuki işlevi kararın kesinleşmesini sağlamasıdır. Kesin hüküm ilkesi uyarınca kararı veren mahkeme dahi olağan kanun yolları tüketildikten sonra o kararı değiştiremez. Davanın tarafları aynı uyuşmazlığı tekrardan yargı mercileri önüne taşıyamazlar. Ancak bu ilkenin mutlak bir biçimde uygulanması ağır hukuki hatalara sahip mahkeme kararlarına da dokunulamaması anlamına gelir. Bu sebeple kesin mahkeme kararlarının da yeniden incelenebilmesi imkânını yaratan olağanüstü kanun yolları, Türk idari yargılama hukukunda kabul edilmiştir. Olağanüstü kanun yolu olarak kabul edilen yargılamanın yenilenmesi yolu, İdari Yargılama Usulü Kanunu'nun (IYYUK) 53. ve 55. maddelerinde düzenlenmiştir. Bu çalışmada idari yargılama usulünde yargılamanın yenilenmesi başvurusuna ilişkin güncel sorunlar araştırılacaktır. Yargılamanın yenilenmesi yolunu anlamlandırabilmek ve var olan sorunları ortaya koyabilmek için kesin hüküm, kanun yolu, yenileme sebebi ve esas karar gibi kavramlara gerektiği ölçüde değinilecektir.

\section{KANUN YOLU VE KESİN HÜKÜM KAVRAMI}

Hatalı veya hukuka aykırı mahkeme kararının düzeltilmesi amacıyla yapılan başvuruya "kanun yolu" adı verilmektedir. Kanun yolu başvurusunun konusu mahkeme kararı olduğu için başvuru, bir mahkemeye yapılacak ve yargısal usullerle görülecektir. Başka bir ifadeyle kanun yolu başvurusu yargısal bir başvurudur. Genel olarak kanun yolu başvurusu, kararı veren mahkemeye yapılabileceği gibi üst derece mahkemeye de yapılabilir. Anayasanın 142. maddesine göre mahkemelerin görev ve yetkileri kanunla düzenleneceği için kanun yolu incelemesi yapma görev ve yetkisi kanunda açıkça düzenlenecektir. Kanun yolu başvurusunun hangi mahkemeye yapılacağı ilgili kanun yolunu düzenleyen kanun hükmünde açıkça belirtilmelidir.

Kanun yollarının birçok işlevi bulunmaktadır. Bunlardan bir tanesi de kanun yolu başvurusu sonuçlanıncaya kadar hükmün kesinleşmesini engellemesidir. ${ }^{1}$ Öğretide kanun yollarına ilişkin olağan - olağanüstü kanun yolu ayrımı yapılmaktadır. Bu ayrım, kesin hüküm kriterine dayanmaktadır. Kesinleşmemiş mahkeme kararlarına karşı yapılan ve sonuçlanıncaya kadar mahkeme kararının kesinleşmesini askıya alan kanun yollarına "olağan kanun yolu”; kesinleşmiş mahkeme kararlarına karşı yapılan kanun yollarına "olağanüstü kanun yolu" adı verilmektedir. ${ }^{2} \mathrm{Bu}$ çalışmanın konusu olan yargılamanın yenilenmesi de olağanüstü kanun yolu kategorisi içinde değerlendirilmektedir. ${ }^{3}$

Olağanüstü kanun yolu olarak yargılamanın yenilenmesine geçmeden önce kesin hüküm kavramına değinmek gerekir. "Kesin hüküm", her şeyden önce mahkeme kararının sahip olabileceği bir etkidir. Ancak her mahkeme kararı kesin hüküm etkisine sahip değildir. Etki olarak kesin hüküm şu üç hususa işaret eder: ${ }^{4}$

a. yargılama yapılan konu hakkında artık yargılama yapılamayacağı,

$b$. kesin hükmün aksinin iddia edilemeyeceği,

c. kesin hükmün uygulanmak zorunda olduğu.

Kesin hüküm kavramı öğretide şekli anlamda kesin hüküm ve maddi anlamda kesin hüküm olmak üzere ikiye ayrılmaktadır. Hükme karşı başvurulabilecek kanun yolunun bulunmaması halinde hüküm şekli anlamda kesinleşir. Şekli anlamda kesin hüküm iki ihtimalde gerçekleşir.

\footnotetext{
${ }^{1}$ PEKCANITEZ, Hakan/ATALAY, Oğuz/ÖZEKES, Muhammet: Medeni Usul Hukuku, 5. Baskı, Vedat Kitapçıllk, İstanbul 2017, s.453.; KURU, Baki/ARSLAN, Ramazan/YILMAZ, Ejder: Medeni Usul Hukuku, 25. Bask1, Yetkin Yayınları, Ankara 2014, s.573, 574.

2 PEKCANITEZ/ATALAY/ÖZEKES, s, 453.; KURU/ARSLAN/YILMAZ, s.574, 575.

${ }^{3}$ GÖZÜBÜYÜK, A. Şeref: Yönetsel Yarg1, 35. Bask1, Turhan Kitabevi, Ankara 2016, s.540.; KAPLAN, Gürsel: İdari Yargılama Hukuku, Ekin Yayınları, Bursa 2016, s.466.; KALABALIK, Halil: İdari Yargılama Usulü Hukuku, 14. Bask1, Seçkin Yayınları, Ankara 2020, s.433.

${ }^{4}$ TANSUĞ, Çağla: İdari Yargılama Hukukunda Yargılamanın Yenilenmesi, Beta Yayınları, İstanbul 2016, s.5, 6.
} 
Birinci ihtimalde hüküm, ilk derece mahkemesi kararının kesin olması sebebiyle baştan kesindir. Bu ihtimalde ilk derece mahkemesinin kararına karşı kanun yoluna başvurmak mümkün değildir. İkinci ihtimalde ise karara karşı süresinde kanun yoluna başvurulmamış, kanun yoluna başvurmaktan feragat edilmiş, kanun yoluna başvurulmuş ancak başvuru reddedilmiş ve artık başvurulabilecek kanun yolu kalmamış yani kanun yolları tüketilmiştir. ${ }^{5}$

Şekli anlamda kesin hükmün maddi anlamda da hukuki gerçeği yansıttığı kabul edilmektedir. Maddi anlamda kesin hüküm, mahkeme kararının artık değişmeyeceği, olağan kanun yoluna başvurulamayacağı ve aynı konudaki davada bağlayıcı olacağını ifade eder. Maddi anlamda kesin hükümle birlikte yargının birbiriyle çelişen kararlar vermesinin önüne geçilmiş ve böylece hukuki barış ortamı sağlanmış olur. ${ }^{6}$

Kesin hüküm etkisi yalnızca mahkemeye karşı öne sürülmez. Davanın tarafları ve diğer kişiler için de geçerli bir etki olabilir. İdari yargıda iptal edilen işlem genelse işlemden doğrudan veya bireysel bir işlem aracılığıyla etkilenen herkes için etki doğurur. ${ }^{7}$ İptal davasında davanın reddine ilişkin kararın kesin hüküm teşkil etmediği de kabul edilmektedir. ${ }^{8}$ Sübjektif bir hakkın ihlal edilmesinden kaynaklanan hukuki uyuşmazlığın çözümü için açılan tam yargı davasında verilen karar, davanın tarafları için kesin hüküm oluşturur. Başka bir ifadeyle tam yargı davasında kesin hükmün etkisi nispidir. ${ }^{9}$ Kesin hüküm etkisi kamu düzenine ilişkin olduğundan idari yargıda yargıç tarafından resen dikkate alınır. ${ }^{10}$

Şekli anlamda kesin hükme karşı olağan kanun yoluna başvurmak mümkün değilse de olağanüstü kanun yoluna başvurmak mümkündür. IYYUK'ta düzenlenen olağanüstü kanun yolları; kanun yararına temyiz ve yargılamanın yenilenmesidir. Olağanüstü kanun yollarından sadece yargilamanın yenilenmesi yolu hükme etki etme potansiyeline sahiptir. IYYUK'un 51. maddesi uyarınca kanun yararına temyiz sonucu verilen bozma kararının, kesinleşmiş mahkeme kararının hukuki sonuçlarına herhangi bir etkisi bulunmaz.

\section{YARGILAMANIN YENILENMESI YOLUNUN GEREKLİLİĞi}

Mahkeme kararının şekli anlamda kesinleşmesiyle birlikte hukuki gerçeği yansıttı̆̆ kabul edilir. Bu nedenle kararı veren mahkeme dahi artık kararı değiştiremez. Ancak bu kuralın mutlak biçimde uygulanması büyük yanlışlıklara ve hatalara sahip mahkeme kararlarının düzeltilememesi anlamına geleceğinden hukuka aykırı sonuçlar doğması mümkündür. Bu nedenle şekli anlamda kesinleşmiş mahkeme kararlarına karşı belirli süre içinde ve belirli sebeplere dayalı olarak başvurulması anlamına gelen yargılamanın yenilenmesi yolu öngörülmüştür. ${ }^{11}$ Yargılamanın yenilenmesine kesin hükme karşı başvurulabildiği için yargılamanın yenilenmesi kesin hükmün istisnası olarak ifade edilmektedir. ${ }^{12}$

Yargılamanın yenilenmesi istemi kabul edildiğinde daha önce kesinleşen hukuki uyuşmazlık canlanır. Kesinleşen hukuki uyuşmazlığın canlanmasından dolayı kesin hüküm ilkesinden beklenen hukuki güvenliğin zedeleneceği düşünülebilir. Ancak kabul edilemez

\footnotetext{
${ }^{5}$ PEKCANITEZ/ATALAY/ÖZEKES, s.433.; KURU/ARSLAN/YILMAZ, s.653, 654.

${ }^{6}$ PEKCANITEZ/ATALAY/ÖZEKES, s.433, 434.; KURU/ARSLAN/YILMAZ, s.656.

${ }^{7}$ GÖZÜBÜYÜK, A. Şeref/TAN, Turgut: İdare Hukuku C. 2 İdari Yargılama Hukuku, 8. Bask1, Turhan Kitabevi, Ankara 2016, s.550, 551.

${ }^{8}$ TUNCAY, Aydın H./ÖZDEŞ, Orhan/BAŞPINAR, Recep: “İdari Yargılama Usulü”, Yüzyıl Boyunca Danıştay 1868 - 1968, Türk Tarih Kurumu Basımevi, Ankara 1968, s.696, 697.; ULUSOY Ali D.: Yeni Türk İdare Hukuku, Yetkin Yayınları, Ankara 2019, s.777.; İptal davalarında davanın reddi kararının davacılar açısından kesin hüküm teşkil etmemesinin idare hukukunun genel ilkelerinden olduğuna ilişkin görüş için bkz. TEKİNSOY, M.Ayhan: “Danıştay'ın Temyiz İncelemesi Üzerine Verdiği Kararların Uygulanması”, İnönü Üniversitesi Hukuk Fakültesi Dergisi, 5(2), 2014, s.34.

9 TUNCAY/ÖZDEŞ/BAŞPINAR, s.697.

${ }^{10}$ YAŞAR, Hasan Nuri: İdari Yargı Kararlarının Etkinleştirilmesi Arayışında İdari Yargı İdari Yargıç Yargısal Emir, On İki Levha Yayınları, İstanbul 2013, s.125.; GÖZÜBÜYÜK/TAN, s.551.

${ }^{11}$ PEKCANITEZ/ATALAY/ÖZEKES, s.490.; KAPLAN, s.466,467.; KALABALIK, s.433.; ÇAĞLAYAN, Ramazan: İdari Yargı Kararlarına Karşı Başvuru Yolları (Fransa - Türkiye Mukayeseli Bir Deneme), Seçkin Yayınları, Ankara 2017, s.429.

12 YILDIRIM, Ramazan: “Türk İdari Yargısında Yargılamanın Yenilenmesi”, Prof. Dr. Nuri Çelik’e Armağan, Marmara Üniversitesi Hukuk Fakültesi, C. 1, s.419.

"Bir yargı yerince yasada gösterilen usullere göre verilen karar, itiraz ve temyiz yollarından geçerek veya itiraz ve temyiz süreleri sona ererek kesinleştikten sonra yargılamanın iadesi gibi bazı istisnaların dışında artık değişmez bir nitelik kazanır, hiçbir makam, merci, hatta kararı vermiş olan yargı yeri dahi başka bir kararıyla onu değiştiremez." Danıştay 5. Dairesi, 06. 11. 2002, E. 1999/2310 K. 2002/4242. (Lexpera)
} 
yanlışlıklara ve hatalara sahip bir mahkeme kararının hukuk düzeninde varlığını sürdürmesi, yargıya olan güveni zedeler. Bireylerin yargıya olan güvenlerini zedelememek için süre ${ }^{13}$ ve sebeple sınırlı olarak yargılamanın yenilenmesi yoluyla kesin hükmün ortadan kaldırılması gereklidir. ${ }^{14}$

\section{YARGILAMANIN YENILENMESI YOLUNUN HUKUKİ REJIMI}

\section{A. Yargılamanın Yenilenmesi Sebeplerinin Sınırlılı̆g}

Öğretide idari yargıda yargılamanın yenilenmesi talebinin İYUK'un 53/1. maddesinde ${ }^{15}$ sayılan sebeplere dayanması ve mahkemenin de bu sebeplere dayanarak yenileme talebini kabul edebileceği ifade edilmektedir. ${ }^{16}$ IYUK'un 53/1. maddesinde "yargılamanın yenilenmesinin aşağı da yazıll sebeplere dayanılarak istenebileceğinin” düzenlenmesi bu görüşün pozitif dayanağıdır. Ayrıca IYYUK'un 55/3. maddesinde kanunda yazılı sebeplere dayanmayan yargılamanın yenilenmesi istemlerinin reddine karar verileceği düzenlenmiştir.

IYYUK'ta IYYUK'a yapılan göndermeler "bu kanun" ifadesiyle yapılmakta, diğer kanunlara yapılan göndermeler "diğer kanun", "başka kanun”, "özel kanun” gibi ifadelerle yapılmaktadır. Bu nedenle IYYUK' un 55/3. maddesindeki kanunda yazılı sebepler ifadesini IYYUK' la birlikte diğer kanunlarda yazan diğer sebepler olarak anlamlandırmak mümkündür. ${ }^{17}$

Bu durumda, yarg1lamanın yenilenmesi sebeplerinin IYYUK'ta sınırlı olmadığı ve AYM'nin bireysel başvuru sonucunda verdiği ihlal kararının ardından 6216 Sayılı Anayasa Mahkemesinin Kuruluşu ve Yargılama Usulleri Hakkında Kanun'un 50/2. maddesi uyarınca yeniden yargılama yapılması için dosyanın mahkemeye gönderilmesinin yargılamanın yenilenmesi sebebi sayılıp sayılmayacağı tartışılabilir. ${ }^{18}$ Mahkeme kararından kaynaklanan bir ihlalin varlığ durumunda AYM, ihlalin giderilmesi amacıyla yeniden yargılama yapılması için kararı veren mahkemeye dosyayı gönderebilmektedir. Yeniden yargılamanın söz konusu ihlali giderecek biçimde ve dosya üzerinden yapılmas1 gerekir.

AYM'nin yeniden yargılama yapılmak üzere dosyayı ilgili mahkemeye göndermesinin; açıkça yargılamanın yenilenmesi sebepleri arasında sayılmaması, söz konusu yeniden yargılamanın dosyanın gönderildiği mahkeme tarafından yapılmasının zorunlu olması ve kabule

13 IYYUK'un 53/3. maddesinde yargılamanın yenilenmesine başvurulabilecek süreler üç kategoride toplanmıştır. Bu ayrım yargılamanın yenilenmesi sebeplerine dayanmaktadır. IYUK'un 53/1-h. maddesindeki sebebe dayanılarak yapılan istemlerde 10 y1l, IYUK'un 53/1-1. maddesindeki sebebe dayanılarak yapılan istemlerde 1 yıl ve diğer sebeplere dayanılarak yapılan istemlerde ise 60 günlük süreler öngörülmüştür. Sürelerin başlangıç tarihleri dayanılan sebebin istemde bulunan yönünden gerçekleştiği tarihi izleyen günden başlar. Ancak IYYUK'un 53/1-1. maddesindeki sebebe dayanılarak yapılan başvurularda süre AİHM kararının kesinleşme tarihinden itibaren başlar.

14 TANSUĞ, s.9. Yargılamanın yenilenmesi yolunun gerekliliğini adalet kavramıyla ilişsilendiren görüş için ayrıca bkz. KAPLAN, s.467.

${ }^{15}$ IYYUK m.53/1: "Danıştay ile bölge idare, idare ve vergi mahkemelerinden verilen kararlar hakkında, aşağıda yazılı sebepler dolaylsiyla yargilamanin yenilenmesi istenebilir.

a) Zorlayıcı sebepler dolayısıyla veya lehine karar verilen tarafin eyleminden doğan bir sebeple elde edilemeyen bir belgenin kararın verilmesinden sonra ele geçirilmiş olması,

b) Karara esas olarak alınan belgenin, sahteliğine hükmedilmiş veya sahte olduğu mahkeme veya resmi bir makam huzurunda ikrar olunmuş veya sahtelik hakkındaki hüküm karardan evvel verilmiş olup da yargılamanın yenilenmesini isteyen kimsenin karar zamanında bundan haberi bulunmamış olması,

c) Karara esas olarak alınan bir ilam hükmünün, kesinleşen bir mahkeme kararlyla bozularak ortadan kalkmasl,

d) Bilirkişinin kasıtla gerçeğe aykırı beyanda bulunduğunun mahkeme kararıyla belirlenmesi,

e) Lehine karar verilen tarafin, karara etkisi olan bir hile kullanmış olması,

f) Vekil veya kanuni temsilci olmayan kimseler ile davanın görülüp karara bağlanmış bulunması,

g) Çekinmeye mecbur olan başkan, üye veya hâkimin katılmasıly karar verilmiş olması,

h) Taraflarl, konusu ve sebebi ayn olan bir dava hak-kında verilen karara aykurl yeni bir kararın verilmesine neden olabilecek kanuni bir dayanak yokken, aynı mahkeme yahut başka bir mahkeme tarafindan önceki ilamın hükmüne aykırı bir karar verilmiş bulunması.

ı) Hükmün, Insan Haklarını ve Ana Hürriyetleri Korumaya Dair Sözleşmenin veya eki protokollerin ihlâli suretiyle verildiğinin, Avrupa İnsan Hakları Mahkemesinin kesinleşmiş kararıyla tespit edilmiş olması veya hüküm aleyhine Avrupa Insan Hakları Mahkemesine yapılan başvuru hakkında dostane çözüm ya da tek taraflı deklarasyon sonucunda düşme karart verilmesi."

${ }^{16}$ GÖZÜBÜYÜK/TAN, s.1013, 1014.; KAPLAN, s.467, 468.; KALABALIK, s.433 vd.

17 TANSUĞ, s.23 - 25.; AKYILMAZ, Bahtiyar/SEZGINER, Murat/KAYA, Cemil: Türk İdari Yargılama Hukuku, Savaş Yayınevi, Ankara 2019, s.715.

${ }_{18}$ Yeniden yargılama yapılması için dosyanın mahkemeye gönderilmesini yargılamanın yenilenmesi sebebi sayan yazarlar bulunmaktadır. Bkz. GÖZÜBÜYÜK/TAN, s.1017.; KARAHANOĞULLARI, Onur: İdari Yarg1 İdarenin Hukuka Zorlanması (Yarg1 Kararlarına Dayalı Bir İnceleme), Turhan Kitabevi, Ankara 2019, s.752.; PEKCANITEZ/ATALAY/ÖZEKES, s.494, 495. 
bağlı olmamas ${ }^{19}$, yeniden yargılama yapılmasının belirli bir süreye bağlanmaması hususları göz önüne alındığında AYM'nin bireysel başvuru sonucunda verdiği ihlal kararının teknik olarak yargılamanın yenilenmesi sebebi sayılamayacağı söylenebilir. ${ }^{20}$ Kanun koyucunun aynı kavramları kullanmaktan kaçınmış olması, usul kanunlarındaki yargılamanın yenilenmesine ilişkin kurallara atıf yapmaması ve özellikle yeniden yargılamanın mümkünse dosya üzerinden karara bağlanması yeniden yargılama ile yargılamanın yenilenmesinin aynı kurumlar olmadığını düşündürmektedir. ${ }^{21}$

AYM de yeniden yargılama yapılmak üzere dosyanın ilgili mahkemeye gönderilmesini usul kanunlarında yer alan yargilamanın yenilenmesi kanun yolundan farklı olarak "bireysel başvuruya özgü bir giderim yolu” olarak nitelendirmektedir. AYM'ye göre dosyanın kendisine gönderilmesinin ardından bireysel başvuru kararında tespit edilen ihlali ve ihlalin sonuçlarını ortadan kaldıracak biçimde yeniden yargılama yapacak olan mahkemenin yargılama sebebinin varlığını tartışma imkânı yoktur. Ayrıca, lehine ihlal kararı verilen kişi veya ilgililerin talepte bulunma zorunluluğu bulunmamaktadır. ${ }^{22}$

6216 Say1lı Kanun'un 50/2. maddesiyle IYYUK'un 53/1-1. maddesinin benzerliği düşünüldüğünde AYM'nin ihlal kararının da yargılamanın yenilenmesi sebepleri arasına dahil edilmesi gerektiği düşünülebilirse de AYM kararının yargılamanın yenilenmesi sebebi oluşturup oluşturmadığını kararı veren mahkemenin tartışması mümkün olmadığı için AYM'nin verdiği ihlal kararının yargılamanın yenilenmesi sebepleri arasında açıkça sayılması da pek mümkün görünmemektedir. ${ }^{23}$

İdari yargılama hukukunda yargılamanın yenilenmesi sebepleri IYYUK'un 53/1. maddesinde sayılan sebeplerden ibaret değildir. 2017 Anayasa değişiklikleriyle birlikte disiplin mahkemeleri hariç askeri mahkemelerin kurulması yasaklanmış ve Askeri Yüksek İdare Mahkemesi (AYIM) kapatılmıştır. ${ }^{24}$ IYUK'a 21. 03. 2018 Tarih ve 7103 Sayılı Kanun'la eklenen geçici 9. madde uyarınca kapatılan AYİM'in bağımsız ve tarafsız olmadığı iddiasıyla AİHM'e başvuru yapılmış olması da bir yargılamanın yenilenmesi sebebidir. Geçici 9. maddenin yürürlüğe girdiği tarih itibariyle AİHM'e yapılan başvurunun derdest olması halinde maddenin yürürlüğe girdiği tarihten itibaren üç ay içinde veya başvurunun iç hukuk yollarının tüketilmemesi sebebiyle AİHM tarafından kabul edilemezlik kararının tebliği tarihinden itibaren üç ay içinde Ankara idare mahkemelerinden yargılamanın yenilenmesi talep edilebilir. Kanun koyucunun söz konusu yargılamanın yenilenmesi sebebini kabul etmesiyle kapatılan AYİM'nin bağımsız ve tarafsız olmadığını dolaylı olarak kabul ettiği söylenebilir. ${ }^{25}$

Danıştay kararlarına bakıldığında yargılamanın yenilenmesi sebeplerinin IYYUK'ta sınırlı olarak sayıldığı hususu açıkça vurgulanmakta ve sayılan sebeplerden herhangi birisine girmeyen bir sebebe dayanılarak yapılan başvurunun reddine karar verilmektedir. Misalen AİHM'ye yapılan başvurunun Adalet Bakanlığı İnsan Hakları Tazminat Komisyonuna yönlendirilmesinin ardından söz konusu komisyonca makul sürede yargılanma hakkının ihlal edildiği gerekçesiyle verilen tazminat ödenmesine ilişkin karara dayanılarak yapılan yargılamanın yenilenmesi başvurusunu inceleyen Danıştay; İnsan Hakları Tazminat Komisyonunun Adalet Bakanlığ bünyesinde bulunan idari bir kurul olduğu ve verdiği kararların yargısal olmadığı saptamasını

19 “Anayasa Mahkemesinin, tespit edilen ihlalin giderilmesi amacıyla yeniden yargılama yapılmasına hükmettiği hallerde, ilgili usul kanunlarında düzenlenen yargılamanın yenilenmesi kurumundan farklı olarak yargılamanın yenilenmesi sebebinin varlığının kabulü ve önceki kararın kaldırılması hususunda derece mahkemesinin herhangi bir takdir yetkisi bulunmamaktadır. Zira ihlal kararı verilen hallerde yargılamanin yenilenmesinin gerekliliği hususundaki takdir derece mahkemelerine değil ihlalin varlı̆̆ını tespit eden Anayasa Mahkemesine bırakılmıştır.” Bkz. AYM, Başvuru Numaras1: 2016/14563, Karar Tarihi: 28. 11. 2019. (AYM Kararlar Bilgi Bankasi)

20 TANSUĞ, s. $28-30$.

${ }^{21}$ KARAMAN, Ebru: Karşılaştırmalı Anayasa Yargısında Bireysel Başvuru Yolu, On İki Levha Yayıncılık, İstanbul 2013, s.311.

${ }^{22}$ AYM, Başvuru Numarası: 2016/12506, Karar Tarihi: 07. 11. 2019. (AYM Kararlar Bilgi Bankası)

${ }^{23}$ TANSUĞ, s.30, 31.

${ }^{24} 1972$ yılında AYİM'in kurulması ile idari yargının birliği ve bütünlüğünün zedelendiği, idari yargı alanının parçalı bir görünüm arz ettiği eleştirileri yapılmaktaydı. Parçalı bir görünüm arz eden idari yargı alanı, 1982 Anayasasında da korunmuştu. Bkz. DURAN, Lütfi: “İdari Yarg1 Adlileşti”, İdare Hukuku ve İlimleri Dergisi, 3(1-3), 1982, s.56. 2017 yılında yapılan anayasa değişikliği sonucunda AYİM'in kapatılmasıyla idari yargı alanının tekrar bütünlüğe kavuştuğu söylenebilir.

25 ÜSTÜN, Gül: "2577 Sayılı İdari Yargılama Usulü Kanununda Öngörülen Yeni Bir Yargılamanın Yenilenmesi Sebebi: Geçici 9. Madde”, Hukuk Araştırmaları Dergisi, 25(1), Haziran 2019, s.20. 
yapmış, İYUK'un 53/1-1. maddesindeki sebebin gerçekleşmiş sayılabilmesi için hükmün, İnsan Haklarını ve Ana Hürriyetleri Korumaya Dair Sözleşmenin veya eki protokollerin ihlâli suretiyle verildiğinin AIHHM'nin kesinleşmiş kararıyla tespit edilmiş olması gerektiğini ifade etmiş ve söz konusu komisyon kararının AİHM kararı sayılmasına olanak bulunmaması ve yenileme sebeplerinin kıyas yoluyla genişletilmesinin mümkün olmaması sebebiyle yenileme başvurusunun reddine karar vermiştir. ${ }^{26}$

\section{B. Yargılamanın Yenilenmesi Başvurusuna İlişkin Tartışmalar}

1. Yargılamanın Yenilenmesi Yoluna Başvurulabilecek Kararlar

a. Kesinleşmiş Mahkeme Kararları Konusundaki Tartışma

IYYUK'un 53/1. maddesi uyarınca Danıştay, bölge idare mahkemesi ile idare ve vergi mahkemelerinin kararlarına karşı yargılamanın yenilenmesi yoluna başvurulabilir. Yargılamanın yenilenmesi, yapılan bir yargılama faaliyetinin varlığını gerektirdiğinden yargı kararları başvuru konusu edilebilir. İdari nitelikteki Danıştay kararlarına karşı yargılamanın yenilenmesi yoluna başvurulamaz. ${ }^{27}$

Yargılamanın yenilenmesini olağanüstü bir kanun yolu olarak nitelendiren öğreti ve yarg1 kararlarında yargılamanın yenilenmesi yoluna mahkemelerin sadece kesin/kesinleşmiş kararlarına karşı yapılabileceği ifade edilmektedir. ${ }^{28}$ IYUK'un 53/1. maddesine göre Danıştay, bölge idare, idare ve vergi mahkemelerinden verilen kararlar hakkında yargılamanın yenilenmesi istenebilir. IYYUK'un ne 53. ne de 55. maddesinde bu mahkemelerin kesin/kesinleşmiş kararlarına karşı yargılamanın yenilenmesi yoluna başvurulabileceğine ilişkin bir sınırlandırma yapılmamıştır. HMK'nın 374/1. maddesinde ise bu sınırlandırmanın yapılmış olması sorunun kaynağını oluşturmaktadır.

IYYUK'un 53/1-c. maddesinde yargılamanın yenilenmesi sebebi olarak karara esas alınan bir ilam hükmünün mahkeme kararıyla bozulmuş olması halinde bozulan mahkeme kararının "kesinleşmiş" olmasının açıkça aranması ve IYUK'un 51/1. maddesinde düzenlenen kanun yararına temyiz yoluna başvurulabilmesi için mahkeme kararlarının kesin veya kesinleşmiş olmasının açıkça aranması bu sorunu desteklemektedir. Çünkü kanun koyucu, mahkeme kararının kesinleşmesini aradığı durumları açıkça ortaya koyabilmektedir. ${ }^{29}$

1982 tarihinden önce idari yargılama usulünü düzenleyen 3546 Sayılı Şurayı Devlet Kanunu ile 521 Sayılı Danıştay Kanunu'nda da yargılamanın yenilenmesi yoluna başvurulabilmesi için kararın kesinleşmiş olması şartı belirtilmemişken 669 Sayılı Şurayı Devlet Kanunu'nda "Vicahen ita edilen veya glyaben lahik olupta itirazı alelhüküm müddeti mürur etmiş olan hükümler hakkında esbabı âtiyeden dolayı bir defaya mahsus olarak iadei muhakeme talep olunabilir" hükmüne yer verilmiştir. Ayrıca 669 Sayılı Kanun'da yargılamanın yenilenmesine iliş̧kin olarak HUMK'a gönderme yapan bir değişiklik yapılmış ve gönderme yapılan HUMK'da da kararın kesin olarak verilmiş olması veya kesinleşmiş olması şartı aranmıştır. Sonuç olarak, 669 Sayılı Şurayı Devlet Kanunu'ndan sonra hiçbir kanuni düzenlemede yargılamanın yenilenmesi yoluna mahkemelerin sadece kesin/kesinleşmiş kararlarına karşı başvurulabileceğine yönelik bir sınırlamaya yer verilmemiştir. Tüm bu belirlemelerin ardından Danıştay, bölge idare, idare ve vergi mahkemelerinin kesinleşmemiş kararlarına karşı yargılamanın yenilenmesi yoluna başvurulabileceğini iddia etmek pekâlâ mümkün görünmektedir.

Danıştay 10. Dairesi, 1986 yılında verdiği bir kararda yargılamanın yenilenmesi istemine başvurulan kararın kesinleşmemiş olması sebebiyle yenileme başvurusunun reddedilmesinde hukuki isabet görmemiştir. ${ }^{30}$ Ancak Danıştay'ın bu kararından sonraki kararlarında yargılamanın

\footnotetext{
${ }^{26}$ Danıştay 2. Dairesi, 06. 02. 2018, E. 2016/5116 K. 2018/480. (Danıştay Bilgi Bankas1)

${ }^{27}$ Danıştay 1. Dairesi, 06. 12. 2011, E. 2011/1663 K 2011/1949. (Legalbank)

${ }^{28}$ GÖZÜBÜYÜK, s.540 vd.; ODYAKMAZ, Zehra: Türk İdari Yargılama Usulünde Kararlara Karşı Başvuru Yolları, Alfa Yayınları, İstanbul 1993, s.94.

${ }^{29}$ ÇAĞLAYAN, s.433.; TANSUĞ, s.97, 98.

30 “Anılan maddeden de anlaşılacă̆ı üzere Danıştay ile İdare ve Vergi Mahkemelerince verilen kararların yargılamanın yenilenmesi yoluyla yeniden incelenebilmesi için yasada belirtilen kanun yollarının tüketilerek kesinleşmiş olması yolunda bir hüküm getirilmemiştir.

Her ne kadar Hukuk Usulü Muhakemeleri Kanununun 445.maddesinde katiyen verilen veya katiyet iktisap etmiş olan kararlar hakkında iade-i muhakeme talep olunabileceği hükme bağlanmış ise de, yukarıda anılan 53. maddesinin 3. fikrasında yargılamanın yenilenmesinde Hukuk Usulü Muhakemeleri Kanununun sadece süreye ilişkin hükümlerinin klyas yoluyla uygulanacă̆ belirtilmiş olup, mahkeme kararının kesinleşmiş olacă̆l yolunda ne anılan maddede, ne de
} 
yenilenmesi yoluna kesinleşmiş kararlara karşı gidilebileceği sürekli ifade edilmiştir. Danıştay’a göre olağanüstü bir kanun yolu olan yargılamanın yenilenmesi yoluna başvurulabilmesi için olağan kanun yollarının tüketilmesi veya süresi içinde bu yollara başvurulmaması gerekir. Ayrıca bir hüküm kesinleşmedikçe ona karşı yargılamanın yenilenmesi yoluna gidilemeyeceği gibi; yargılamanın yenilenmesi, sadece kesinleşmiş olan esasa ilişkin nihai kararlara karşı başvurulabilecek bir kanun yoludur. ${ }^{31}$

Yerleşik Danıştay içtihatları ve öğretide ifade edildiği üzere yargılamanın yenilenmesinin olağanüstü bir kanun yolu olduğu göz önüne alındığında bu yola sadece kesinleşmiş mahkeme kararlarına karşı başvurulabileceğinin kabulü gerekir. Ancak olağan - olağanüstü kanun yolu ayrımı, kesinleşmiş - kesinleşmemiş mahkeme kararı ayrımına dayanılarak yapılan bir ayrımdır. Başka bir ifadeyle kanun yoluna ilişkin yapılan bu ayrım, kanun yoluna başvuru yapılabilecek kararların kesinliği kriterine göre yapılmaktadır. Kanun yolunun olağanüstü olması sebebiyle sadece kesin kararlara karşı başvuru yapılabileceği sonucuna varılması, kriterle ulaşılan sonuç arasındaki bağıntıyı tersine çevirmek anlamına gelmektedir.

Yargılamanın yenilenmesi başvurusunun, olağan kanun yolları aşamasında bulunan veya olağan kanun yollarına başvurulmayıp da başvuru süresi henüz geçmeyen ve dolayısıyla kesinleşmemiş mahkeme kararlarına karşı yapılması durumunda Danıştay, başvurunun incelenmeksizin reddine karar verilmesi gerektiğini ifade etmektedir. ${ }^{32}$

\section{b. Esasa İlişkin Nihai Kararlara İlişkin Tartışma}

IYYUK'un 53/2. maddesine göre "yargılamanın yenilenmesi istekleri esas kararı vermiş olan mahkemece karara bağlanır." IYUK'un 53/2. maddesindeki bu kuralı yargılamanın yenilenmesi yoluna başvurulabilecek kararlar açısından bir sınırlandırma olarak yorumlayan öğreti ve Danıştay, mahkemelerin esas hakkında verdikleri nihai kararlara karşı yargılamanın yenilenmesi yoluna başvurulabileceğini ifade etmektedir. ${ }^{33}$

IYYUK'un 53/1. maddesi, 05. 04. 1990 Tarih ve 3622 Say1lı Kanun'la değiştirilmeden önce Danıştay ile idare ve vergi mahkemeleri kararlarına karşı yargılamanın yenilenmesi yoluna başvurulabileceğini düzenlemekteydi. Bölge idare mahkemelerinin madde metnine eklenmesinin gerekçesi olarak bölge idare mahkemelerinin sahip olduğu esas hakkında karar verme yetkisi gösterilmiştir. ${ }^{34}$ Bölge idare mahkemesinin itiraz üzerine verdiği esas hakkında karar kesin olduğu

Hukuk Usulü Muhakemeleri Kanununun uygulanacă̆ı halleri düzenleyen 2577 sayll kanunun $31 . m a d d e s i n d e$ herhangi bir atıfta bulunulmamıştır.

Bu durumda İdare Mahkemesince işin esasına girilerek 2577 sayıl yasanın 53.maddesinde sayılan yargılamanın yenilenmesi sebeplerinin bulunup bulunmadığı hususunun araştırılması gerekirken yargılamanın yenilenmesi yoluyla incelenmesi istenilen kararın kesinleşmediği gerekçesi ile istemin reddedilmesinde hukuki isabet görülmemiştir." Danıştay 10. Dairesi, 29. 05. 1986, E. 1986/301 K. 1986/1330. (Kazanc1)

31 "Yargllamanın yenilenmesi, bazı ă̆ır yargılama hatalarından ve noksanlarından dolayl, maddi anlamda kesin hükmün bertaraf edilmesini ve daha önce kesin hükme bağlanmıs olan bir dava hakkında yeniden yargılama ve inceleme yapılmasını sağlayan olağanüstü bir kanun yolu olup; metni yukarlya alınan maddede sayılan sebeplerin varlığı halinde, kesin hükme ilişkin esas kararl vermiş olan mahkemeden istenebilir.

Buna göre, bir hüküm kesinleşmedikçe, ona karşı yargılamanın yenilenmesi yoluna gidilemeyeceği gibi; yargılamanın yenilenmesi, sadece kesinleşmiş olan esasa ilişkin nihai kararlara karşı başvurulabilecek bir kanun yolu olması nedeniyle de, bir hüküm mahkemesi kararı Danıştay incelemesinden geçmek suretiyle kesinleşmiş olsa bile yargılamanın yenilenmesi yoluyla hüküm mahkemesi kararının değiştirilmesi istenebileceğinden, Danıştay'ın temyiz veya karar düzeltme talebi üzerine verdiği kararlara karşı yargılamanın yenilenmesi yoluna başvurulamayacağ açıtır.” Danıştay 5. Dairesi, 19. 12. 1996, E. 1995/4339 K. 1995/4159. (Legalbank)

32 "Bir kararın, yargılamanın yenilenmesi başvurusuna konu edilebilmesi için, ilk derece mahkemesi sıfatıyla bakılan davada verilmiş olması ve ayrıca, kesinleşmiş, yani kesin hüküm halini almış bulunması gerekmektedir. Uyuşmazlıkta, davacının yargılamanın yenilenmesi talebinde bulunduğu tarih itibariyle henüz kesin hüküm halini almış bir karar mevcut olmayıp, temyiz incelemesi tamamlanmayan bir Mahkeme kararı mevcut olduğundan, kesinleşmemiş olan uyuşmazlı̆̆a yönelik yargılamanın yenilenmesi isteminin incelenmeksizin reddi gerekirken (...)” Danıştay 5. Dairesi, 19. 03. 2013, E. 2013/402 K. 2013/2109. (Legalbank)

${ }_{33}$ ÇAĞLAYAN, s.435.; Danıştay 5. Dairesi, 19. 12. 1996, E. 1995/4339 K. 1995/4159. (Legalbank)

34 "Kanunun 53'üncü maddesine göre, bölge idare mahkemesi kararlarına karşı yargılamanın yenilenmesi istenememektedir. Yerine göre işin esası hakkında karar veren bölge idare mahkemesi kararlarına karşı da yargılamanın yenilenmesinin istenebilmesi uygun olacă̆ından 53'üncü maddede bunu sağlayacak değişiklik yapılmaktadir."

TBMM Dönem: 18 Yasama Yı11: 2, S.Sayısı: 120.

https://www.tbmm.gov.tr/tutanaklar/TUTANAK/TBMM/d18/c042/tbmm18042093ss0120.pdf (Erişim Tarihi: 25. 02. 2020) 
başka bir ifadeyle temyiz yoluyla Danıştay’a götürülemeyeceği için söz konusu kararlara karşı da yargılamanın yenilenmesi yoluna başvuru imkânı getirilmiştir. ${ }^{35}$

IYYUK'un 53/2. maddesi dişında kanunda "esas karar" ifadesi kullanılmamakla birlikte "esasa ilişkin karar" (IYUK m.28/1) ve "esas hakkında karar" (IYYUK m.20/A/1-i, m.20/B/1-h, m.45/4) ifadeleri kullanılmaktadır. Bölge idare mahkemelerinin, itiraz üzerine esas hakkında karar verebildikleri için yargılamanın yenilenmesi başvurusuna konu olabilecek kararı veren mahkemeler arasına dahil edildiğini de düşünecek olursak, IYYUK'un 53/2. maddesindeki esas karar ifadesini lafzi ve tarihsel bir yorumla "esasa ilişkin/esas hakkında karar" olarak anlamak mümkündür. Bu durumda İYUK'un 53/2. maddesindeki kural, yenileme başvurusuna konu olabilecek kararlar bakımından önemli bir sınırlandırma anlamına gelecektir. Ancak esasa ilişkin kararların neler olduğu da mevzuatta belirlenmiş değildir. ${ }^{36}$

Kanun koyucunun esas karar ifadesini söz konusu kararı, esasa ilişkin/esas hakkında karardan ayırmak için kullanmış olabileceği ihtimali düşünüldügünde esas kararın, esasa ilişkin/esas hakkında karar olmadığını söylemek mümkün hale gelecektir. Böylece yargılamanın yenilenmesi yoluna başvurulabilecek kararlar bakımından bir sınırlandırma da ortaya çıkmayacaktır. Ayrıca IYYUK'un 53/2. maddesinde yargılamanın yenilenmesi başvurusunu inceleme yetkisinin sahibinin belirlendiğini ve söz konusu yetkinin üst derece mahkemesine değil uyuşmazlığın asıl yargıcı olan dava mahkemesine verildiğini söylemek de mümkündür. ${ }^{37}$ Kanaatimizce IYUK'un 53/2. maddesindeki kuralı yargılamanın yenilenmesi başvurusunun yapılacağı mahkemeyi belirleyen kural olarak anlamak ve kurala yukarıda bahsedildiği gibi sınırlandırıcı bir işlev yüklememek idari yargının niteliğine daha uygun olacaktır. Misalen idarenin yazılı bildirim tarihine ilişkin olarak hileli davranışlarda bulunmak suretiyle davacının dava açma süresini kaçırmış görünmesine ve davanın süreaşımından reddedilmesine sebep olması mümkündür. Eğer İYUK'un 53/2. maddesindeki kurala sınırlandırıcı bir işlev tanındığında davanın süreaşımından reddi kararına karşı yargılamanın yenilenmesi başvurusu yapilamayacaktır. ${ }^{38}$

Yargılamanın yenilenmesi, "dava konusu uyuşmazlık hakkında verilmiş bir kararın aynı mahkemede tekrar ele alınarak incelenmesine olanak veren, mahkeme kararlarının dayandiğ maddi nedenlerin sakatlı̆̆ının söz konusu edildiği olağanüstü bir kanun yolu"39 olduğu için bir kararın yargılamanın yenilenmesi başvurusuna konu edilebilmesi için kesinleşmiş olmasının yetmeyeceği, uyuşmazlığın esası hakkında "ilk derece mahkemesi sifatıyla verilen ve davanın taraflarl arasındaki maddi uyuşmazlı̆̆ çözümleyen"40 nitelikte bir karar olmas1 gerektiği Danıştay kararlarında vurgulanmıştır.

Danıştay kararlarında esasa ilişkin nihai kararların yargılamanın yenilenmesi başvurusuna konu edilebileceği ifade edilirken ilk derece mahkemesi sıfatıyla verilen kararlardan bahsedilmektedir. Ancak idari yargı sistemimize olağan ve genel kanun yolu olarak istinafin girmesiyle birlikte bölge idare mahkemesinin istinaf isteminin kabulü ile esas hakkında yeniden

6545 Sayılı Kanun'la değiştirilmeden önce IYUK'un 45/4. maddesi şu şekildeydi: “Bölge idare mahkemesi evrak üzerinde yaptığl Inceleme sonunda, maddi vakıalar hakkında edinilen bilgiyi yeter görürse veya İtiraz sadece hukuki noktalara ilişkin ise veya itiraz olunan karardaki maddi yanlışlıkların düzeltilmesi mümkün ise işin esası hakkında karar verir. Aksi halde gerekli inceleme ve tahkikatı kendisi yaparak esas hakkında yeniden karar verir." Öğretide de bölge idare mahkemelerinin esas hakkında karar verme yetkisi bulunduğu için bölge idare mahkemesi kararlarına karş1 yargılamanın yenilenmesi yoluna başvurulabilmesi gerektiği ve dolayısıyla hükmün önceki halindeki "idare ve vergi mahkemeleri” ifadesinin bölge idare mahkemelerini kapsayacak biçimde düşünülmesi gerektiği savunulmuştur. Bkz. YENICE, Kazım/ESIN, Yüksel: Açıklamal1- İçtihatl1- Notlu İdari Yargılama Usulü Kanunu, Arısan Matbaacılık, Ankara 1983, s.740.; YILDIRIM, s.420, 421.

356545 Sayılı Kanun'la değiştirilmeden önce IYYUK'un 45/5. maddesi şu şekildeydi: “Bölge idare mahkemesinin kararları kesindir; temyiz yoluna başvurulamaz."

${ }^{36}$ TEKINSOY, s.27, 28.

${ }^{37}$ HMK'nın 378/1. maddesi şu şekildedir: "Yargılamanın iadesi talebini içeren dilekçe, kararı veren mahkemece incelenir." HMK'nın 378/1. maddesindeki kararı veren mahkemenin, yargılamanın iadesi sebebinin ortaya çıktığ aşamadaki kararı veren mahkeme olarak anlaşılması gerektiğine ilişskin görüş için bkz. ÖZEKES, Muhammet: Pekcanitez Usûl Medenî Usûl Hukuku Cilt III, 15. Bask1, İstanbul 2017, s.2343.

38 İlk derece mahkemelerinin ilk inceleme üzerine verdikleri davanın reddi kararlarının, ilk derece mahkemesi sıfatıyla verilmiş ve kesinleşmiş karar olmaları sebebiyle yargılamanın yenilenmesine konu yapılabileceğine ilişkin görüş için bkz. ASLAN, Zehreddin/BARLASS, İrfan/BERK, Kahraman/ARAT, Nilay/SAYHAN, Şebnem/BARDAKÇI, Mehmet Akif/GÜMÜŞKAYA, Gamze/KAĞITCIOĞLU, Mutlu/ALTINDAĞ, Halil: Açıklamalı ve İçtihatlı İdari Yargılama Usulü Kanunu, Seçkin Yayınları, Ankara 2019, s.411.

${ }^{39}$ Danıştay 10. Dairesi, 17. 06. 1985, E. 1985/474 K. 1985/1274.

${ }^{40}$ Danıştay VDDK, 11. 06. 1999, E. 1998/385 K. 1999/339. (Legalbank) 
karar vermesi mümkün olduğu için bölge idare mahkemesinin esas hakkında verdiği karar, esasa ilişkin nihai karar olmakla birlikte ilk derece mahkemesi sıfatıyla verilmiş bir karar değildir. Ancak bu kararlar da yargılamanın yenilenmesi istemine konu edilebilirler. ${ }^{41}$ IYUK' un 53/2. maddesindeki kurala sınırlandırıcı işlev tanınmaksızın da aynı sonuca ulaşılabilir. Esas hakkında karar verme yetkisine sahip üst derece mahkemelerini ilk derece mahkemesi olarak saymak mümkün değilse de bir kez üst derece mahkemesine başvurulmuşsa ve mahkeme esas hakkında karar vermişse uyuşmazlığın asıl yargıcının artık üst derece mahkemesi haline geldiği ve yargılamanın yenilenmesi başvurusunun da uyuşmazlığın asıl yargıcı olan üst derece mahkemesine yapılacağı kabul edilebilir.

Kanun yolu aşamasında bölge idare mahkemesinin istinaf isteminin reddi ile ilk derece mahkemesi kararının onanmasına ilişkin kararlar ve Danıştay'ın temyiz üzerine verdiği onama ve bozma kararlarının uyuşmazlığın esasını çözen kararlar olmadıkları için yargılamanın yenilenmesi istemine konu edilemeyecekleri kabul edilmektedir. ${ }^{42}$ Danıştay'ın esas karar ifadesine ilişkin yaklaşımı kabul edildiği takdirde davaları esastan sonuçlandıran, taraflar arasındaki maddi uyuşmazlığı çözen nihai karar olmamaları sebebiyle ilk inceleme üzerine verilen kararlar da yargılamanın yenilenmesi istemine konu edilemeyeceklerdir. ${ }^{43}$

İvedi yargılama usulü ile merkezi ve ortak sınavlara ilişkin yargılama usulünde Danıştay’ın temyiz mercii olarak işin esası hakkında verdiği kararlar, taraflar arasındaki maddi uyuşmazlığı çözen kesin kararlardır. Bu sebeple söz konusu kararların da yargılamanın yenilenmesi başvurusuna konu olabileceği söylenebilir. Ancak IYUK m.20/A ve 20/B kapsamındaki uyuşmazlıklarda Danıştay'ın temyiz mercii olarak işin esası hakkında verdiği kararlara karşı yargılamanın yenilenmesi talebinin hangi mahkeme tarafından karara bağlanacağı tartışmalıdır.

\section{Başvurulacak Mahkemeye İlişkin Tartışma}

Öğreti ve yargı kararlarında yargılamanın yenilenmesi yoluna Danıştay, bölge idare mahkemesi ile idare ve vergi mahkemelerinin kesinleşmiş ve esasa ilişkin nihai kararlarına karşı başvurulabileceği kabul edilmektedir. ${ }^{44}$ IYUK'un 53/2. maddesine göre "Yargllamanın yenilenmesi istekleri, esas kararı vermiş olan mahkemece karara bağlanır." 45 Danıştay'a göre "esas karar", yarg1 yerlerince ilk derece mahkemesi sifatılla verilen ve davanın tarafları arasındaki maddi uyuşmazlığı çözümleyen kararları ifade eder. ${ }^{46}$

İdari yargılama hukukunda 2014 yılında yapılan değişiklikler sonucunda istinaf kanun yolu kabul edilmiş; idare ve vergi mahkemelerinin nihai kararlarına karşı bölge idare mahkemelerine istinaf kanun yoluna başvuru imkânı getirilmiştir. IYYUK'un 45/4. maddesi uyarınca bölge idare mahkemesi ilk derece mahkemesinin kararını hukuka uygun bulmadığı takdirde istinaf başvurusunun kabulü ile ilk derece mahkemesinin kararının kaldırılmasına karar verecektir. Bu halde bölge idare mahkemesi işin esası hakkında bir karar verecektir. Bu durumda bölge idare mahkemesinin verdiği kararın esas karar olarak değerlendirilmesi ve bölge idare mahkemesinin istinaf üzerine verdiği karara karşı yargılamanın yenilenmesi yoluna başvurulabilmesi ve başvurunun da bölge idare mahkemesi tarafından karara bağlanması gerekir.

İvedi ve merkezi ve ortak sınavlara ilişkin yargılama usulünde temyiz mercii olarak Danıştay'a istinaf yetkileri verilmiştir. Şöyle ki, IYYK'un 20/A/2-i ve 20/B/1-h. maddelerine göre "Danıştay evrak üzerinde yaptığ inceleme sonunda, maddi vakıalar hakkında edinilen bilgiyi yeterli görürse veya temyiz sadece hukuki noktalara ilişkin ise yahut temyiz olunan karardaki maddi yanlışlıkların düzeltilmesi mümkün ise işin esası hakkında karar verir. Aksi hâlde gerekli inceleme ve tahkikatı kendisi yaparak esas hakkında yeniden karar verir." $\mathrm{Bu}$ hüküm doğrultusunda Danıştay, temyizen incelediği kararın maddi ve hukuki yönlerini denetleyecek ve gerekli görürse inceleme ve tahkikatı kendisi yaparak esas hakkında yeniden bir karar verecektir.

\footnotetext{
41 CANDAN, Turgut: Açıklamalı İdari Yargılama Usulü Kanunu, 6. Baskı, PwC, İstanbul 2015, s.1124.; AKYILMAZ/SEZGINER/KAYA, s.717.

42 AKYILMAZ/SEZGINER/KAYA, s.717.

${ }^{43}$ ÇAĞLAYAN, s.440.

${ }^{44}$ Bkz. IV-B-1-a ve IV-B-1-b

453546 Sayılı Devlet Şurası Kanunu'nun 51/1. maddesinde muhakemenin iadesinin ilamı veren dava dairesi veya Umumi Heyetten istenebileceği; 521 Sayılı Danıştay Kanunu'nun 99/1. maddesinde ise muhakemenin iadesinin esas kararı vermiş olan dava dairesi veya Dava Daireleri Kurulu tarafindan karara bağlanacağı düzenlenmiştir.

${ }^{46}$ Danıştay 7. Dairesi, 28. 10. 2004, E. 2004/2407 K. 2004/2691. (Legalbank) 
Danıştay'ın ivedi ve merkezi ve ortak sınavlara ilişkin yargılama usulüne tabi davalarda yaptığ kanun yolu incelemesine temyiz adı verilmekle birlikte bunun olağan yargılama usulündeki temyiz incelemesinden oldukça farklı ve istinaf yetkilerinin kullanıldığı bir kanun yolu olduğu söylenebilir. ${ }^{47}$

Özel yargılama usulüne tabi davalarda temyiz mercii olarak Danıştay'ın esas hakkında verdiği kararlara karşı hangi mahkemede yargılamanın yenilenmesi yoluna başvurulacağ hususunda, Danıştay kararlarında bir belirsizlik mevcuttur. İhale işlemine karşı açılan bir davada ilk derece mahkemesinin davanın reddi yönündeki kararının temyizi üzerine Danıştay, ilk derece mahkemesinin kararını bozmuş ve işlemin iptaline karar vermiştir. Bu karara karşı yargılamanın yenilenmesi başvurusunu inceleyen Danıştay, esasa ilişkin nihai kararın Danıştay dairesi tarafından verilmiş olması sebebiyle IYUK'un 53/2. maddesi uyarınca esas kararı vermiş olan mahkemenin Danıştay dairesi sayılması gerektiğini ifade etmiştir. ${ }^{48}$

ÇED olumlu kararının iptali istemiyle açılan davada ilk derece mahkemesinin davanın reddi yönündeki kararının temyizi üzerine Danıştay, ilk derece mahkemesinin kararını bozmuş, bazı davacılar yönünden işlemin iptaline bazı davacılar yönünden davanın ehliyet yönünden reddine karar vermiştir. Söz konusu Danıştay kararı üzerine davalı idare tarafindan ilk derece mahkemesinde yargılamanın yenilenmesi talebinde bulunulmuş, ilk derece mahkemesi ise esas kararı veren mahkemenin Danıştay dairesi olması sebebiyle davanın esas kaydını kapatarak dosyayı Danıştay'a göndermiştir. Danıştay ise davanın, ilk derece mahkemesi olarak Danıştay'ın görev alanına giren bir dava olmaması, uyuşmazlığın ivedi yargılama usulüne tabi olması sebebiyle işin esası hakkında karar verildiğini ifade ederek ilk derece mahkemesinin yargılamanın yenilenmesi sebepleri yönünden inceleme yapmayıp dava dosyasının esas kaydını kapatarak Danıştay'a göndermesini hukuken isabetsiz bulmuştur. ${ }^{49}$

Kanaatimizce Danıştay'ın vermiş olduğu esas hakkındaki karar, taraflar arasındaki maddi uyuşmazlığı çözen bir karar olduğu için buna karşı yargılamanın yenilenmesi başvurusu Danıştay'a yapılmalıdır. Yargılamanın yenilenmesi başvurusunun ilk derece mahkemesine yapılması gerektiği kabul edilirse ilk derece mahkemesinden kendisinin vermediği bir karar üzerine yeniden yargılama yapması talep edilmiş olacaktır. $\mathrm{Bu}$ durumun, yargılamanın yenilenmesi başvurusunun "kararı vermiş olan mahkemece karara bağlanması" hususuna aykırılık teşkil ettiği söylenebilir. (IYYK m.53/2)

Danıştay'ın vermiş olduğu esas hakkında karara karşı Danıştay'da yargılamanın yenilenmesi yoluna başvurulacağı kabul edildiğinde şöyle bir sorunun ortaya çıktığı da gözden kaçırılmamalıdır: İlk derece mahkemesi olarak Danıştay’ın görevine giren ve özel yargılama

\footnotetext{
47 "Kanun koyucunun ivedi yargılama usulüne tabi davalarda yargılama sürecini hızlandırmak amacılla farklı bir kanun yolu sistemi öngördüğ̈̈ anlaşılmaktadır. Bu bağlamda, ivedi yargılama usulüne tabi davalarda istinaf yoluna başvuru hakkı kaldırılarak doğrudan temyiz yoluna başvuru usulü getirilmiş, temyiz incelemesinde de Danıştay'a istinaf yolundakine benzer şekilde denetim yapma yetkisi verilmiştir.” AYM, 19. 03. 2015, E. 2014/146 K. 2015/31, RG, 13. 06. 2015, S.29385.

48 "Davanın ivedi yargllama usulüne tabi olması ve mahkemece davanın reddine ilişkin olarak verilen kararın Dairemizce verilen (...) sayıl karar ile bozulması ve dava konusu işlemin iptaline kesin olarak (karar düzeltme yolu kapalı olmak üzere) karar verilmiş olması bakımından Dairemizin anılan kararına yönelik yargılamanın yenilenmesi isteminin İdare Mahkemesince değil Dairemizce karara bağlanması gerekmektedir. Zira İdare Mahkemesince verilen kararın bozulması üzerine dosya Mahkemeye gönderilmeyip esasa ilişkin olarak da nihaî karar Dairemizce kesin olarak verildiğinden, 2577 sayıl Kanun'un 53. maddesinde belirtilen "esas kararl vermiş olan mahkeme"nin bu olayın özelliği itibarılla dairemiz olarak kabulü gerekmektedir.” Danıştay 13. Dairesi, 15. 02. 2016, E. 2015/6064 K. 2016/287. (Danıștay Bilgi Bankası)

49 "Olayda; İdare Mahkemesince her ne kadar, davanın reddi yolundaki Mahkeme kararının Danıştay On dördüncü Dairesinin 23.02.2016 günlü, E: 2015/4429, K: 2016/1079 sayll kararl ile bozularak bir kısım davacılar yönünden işlemin iptaline, bir kısım davacılar yönünden ise davanın ehliyet yönünden reddine kesin olarak karar verilmiş olması nedeniyle Danıştay On dördüncü Dairesinin, 2577 sayll Kanunun 53. maddesinde düzenlenen yargllamanın yenilenmesi istemini karara bağlayacak esas mahkeme olduğu gerekçesiyle dosyanın esas kaydı kapatılarak Dairemize gönderilmişse de, davanın, 2575 sayılı Kanunun 24. maddesindeki Danıştay'ın ilk derece mahkemesi olarak karara bağlayacağı davalardan olmadiğ ve ilk derece Mahkemesi kararının temyiz edilmesi üzerine, temyiz mercii olarak Danıştay On dördüncü Dairesince, uyuşmazlık konusunun ivedi yargllama usulüne tabi olması nedeniyle isin esası hakkında Mahkeme adına karar verildiği sonucuna varıldı̆̆ından; İdare Mahkemesince, 2577 sayll Kanunun 53. maddesinde düzenlenen yargllamanın yenilenmesi sebepleri yönünden inceleme yapılarak bir karar verilmesi gerekirken, dosyanın esas kaydının kapatılarak Danıştay On dördüncü Dairesine gönderilmesinde hukuki isabet görülmemiştir.” Danıştay 14. Dairesi, 27. 02. 2017, E. 2017/563 K. 2017/1072. (Sinerji)
} 
usulüne tabi bir uyuşmazlıkta ${ }^{50}$ temyiz mercii, Danıştay IDDK olacaktır. IDDK'nın vermiş olduğu esas hakkında karara karşı yargılamanın yenilenmesi başvurusu yapıldığında ve başvuru reddedildiğinde red kararına karşı herhangi bir kanun yolu mercii bulunamamaktadır. $\mathrm{Bu}$ durumun dolaylı olarak kanun yolunun kapatılması olarak değerlendirilmesi mümkündür.

\section{Yargılamanın Yenilenmesi Başvurusu Sonrasındaki Süreç}

a. Yargılamanın Yenilenmesi Başvurusunun Kabulü veya Reddi

Yargılamanın yenilenmesi yolu ayrı bir dava mıdır? Danıştay "yeni bir ihtilaf tazammun etmediği cihetle ayrt ve müstakil bir dava ve ihtilaf telakki edilemez" ${ }^{\text {"51 }}$ diyerek yarg1lamanın yenilenmesinin ayrı bir dava olmadığını ifade etmiştir. Danıştay'a göre yargılamanın yenilenmesi, asıl davadan ayrı ve ondan tümüyle bağımsız bir yol olmayıp asıl davanın devamı niteliğinde ve fakat konusu ve sebebi itibariyle ondan farklı bir yargılama derecesidir. ${ }^{52}$ Danıştay'ın yargılamanın yenilenmesi talebinin kabulü halinde istemin yeni bir davaya dönüştüğü ancak talebin kabulü aşamasına kadar olan sürecin önceki yargılamanın devamı niteliğinde olduğunu ifade ettiği kararları da bulunmaktadır. ${ }^{53}$

Yargılamanın yenilenmesi dilekçesi verildikten sonra mahkeme ilk derece mahkemesi sıfatıyla verilen kesin ve nihai bir karar bulunup bulunmadığını, yenileme başvurusunun süresinde yapılıp yapılmadığını ve yenileme sebeplerinden en az birinin bulunup bulunmadığını araştırmalıdır. Bu hususların varlığı tespit edildikten sonra yargılamanın yenilenmesi sebebinin haklılığ 1 araştırılmalıdır. Yenileme sebebi haksızsa mahkeme, yenileme isteminin reddine karar verecektir. ${ }^{54}$ Mahkeme yenileme sebebinin haklı olduğuna karar verirse davaya yeniden bakacak ve karar verecektir. ${ }^{55}$

Yargılamanın yenilenmesi başvurusunun reddi kararı nihai bir karar olduğu için bu karara karş1 olağan kanun yollarına başvurmak mümkündür. ${ }^{56}$ Yargılamanın yenilenmesi başvurusu idare veya vergi mahkemesi kararına karşı yapılmışsa başvurunun reddi kararına karşı bölge idare

\footnotetext{
${ }^{50}$ IYYUK'un 20/A/1-f. ve Danıştay Kanunu'nun 24/1-a. maddeleri uyarınca 6306 Sayılı Afet Riski Altındaki Alanların Dönüştürülmesi Hakkında Kanun uyarınca alınan Cumhurbaşkanı kararlarına karşı açılan davalar ivedi yargılama usulüne tabi olup ilk derece mahkemesi olarak Danıştay'ın görev alanına girmektedir.

${ }^{51}$ Danıştay DDGK, 14. 03. 1952, E. 1952/13 K. 1952/86, RG, 06. 05. 1952, S.8102.

${ }^{52}$ Danıştay 5. Dairesi, 18. 11. 1987, E. 1987/763 K. 1987/1570.

${ }^{53}$ Danıştay 8. Dairesi, 21. 03. 2017, E. 2016/10421 K. 2017/1831. (Lexpera)

${ }^{54}$ IYYUK'un ilk halinde yargılamanın yenilenmesi kanundaki sebeplere dayanmadığı için istem reddedildiğinde Hukuk Usulü Muhakemeleri Kanunu'nu hükümlerine göre para cezasına hükmedileceği düzenlenmişti. IYYUK'un 55/3. maddesi 4001 Sayılı Kanun'la yeniden düzenlenmiş ve para cezasına ilişkin kural madde metninden çıkartılmıştır. Değişikliğin gerekçesi olarak para cezası uygulamasının yargı fonksiyonuyla bağdaşmaması gösterilmiştir. Kanun tasarısının madde gerekçesinde şu ifadelere yer verilmiştir: "Dava hakkı ve bunun bir uzantısı olan kanun yollarına başvurma hakkı, Anayasa ile tanınmış temel hak ve özgürlükler arasında yer alır. Diğer taraftan, hukuk devleti ilkesi, idarî eylem ve işlemlerin hiçbir kısıntıya tabi olmaksızın yargı denetimine tabi tutulmasını gerektirir. Bu itibarla, kişilerin yargılamanın yenilenmesi ve kararın düzeltilmesi istemlerinin reddi halinde onlardan para cezası alınmasını öngören hüküm yargı fonksiyonunun amacı ile bağdaşmadı̆̆ından yürürlükten kaldırılmaktadır."
}

TBMM Dönem: 19 Yasama Y1lı: 3, S.Sayıs1: 409.

https://www.tbmm.gov.tr/tutanaklar/TUTANAK/TBMM/d19/c062/tbmm19062115ss0409.pdf (Erişim Tarihi: 25. 02. 2020)

55 YILDIRIM, s.441. Öğretide Onar, yargılamanın yenilenmesinin üç aşaması olduğunu ifade etmiştir. Bunlar; yargılamanın yenilenmesi sebebinin idari yargı dışındaki bir yetkili merci tarafından tespit edilmesi, tespit edilen sebebin kararı veren mahkeme tarafından geçerli olup olmadığına karar verilmesi ve eğer geçerliyse yenileme başvurusunun kabulüne karar verilmesi ve son olarak davanın yeniden görülmesidir. Bkz. ONAR, Sıddık Sami: İdare Hukukunun Umumi Esasları, C. 3, İsmail Akgün Matbaası, İstanbul 1966, s.1996.; Onar'a benzer biçimde Eroğlu da yargılamanın yenilenmesinin üç aşaması olduğunu ifade etmiştir. Bunlar; idari yargı dışında bir yargı merciinin karar vermesi, yargılamanın yenilenmesi sebebinin idari yargı mercii tarafından geçerli olup olmadığının incelenmesi ve son olarak davanın yeniden görülmesidir. Bkz. EROĞLU, Hamza: İdare Hukuku Dersleri Genel Esaslar, İdari Teşkilat ve İdarenin Denetlenmesi, Sevinç Matbaas1, Ankara 1974, s.424, 425.

${ }^{56}$ NAMLI, Mert: Türk ve Fransız Medeni Usul Hukukunda Yargılamanın Yenilenmesi, Beta Yayınları, İstanbul 2014, s.455.; KARAHANOĞULLARI, s.748.; ASLAN vd., s.417. "Her ne kadar mahkemece yargilamanın yenilenmesi hakkında verilen kararların temyiz edilemeyeceği, olağanüstü kanun yolu olan kanun yararına bozma ile yargilamanın yenilemesi isteklerine karşı ayrıca bir yargı yolu olmadı̆̆ ve mahkemelerin bu istekleri ret kararlarının temyiz edilebileceğine dair bir düzenlemenin İdari Yargılama Usulü Kanununda yer almadı̆̆ ileri sürülerek istek reddedilmişse de yukarıda sözü edilen 2577 sayılı İdari Yargılama Usulü Kanununun 55. maddesinin son fikrası gereğince, yargılamanın yenilenmesi talebinin reddine iliş̧kin kararların temyizinin mümkün olması karşısında istemin reddi yolunda verilen mahkeme kararında hukuki isabet görülmemiştir.” Danıştay 12. Dairesi, 13. 12. 1995, E. 1995/3169 K. 1995/3237. (Danıştay Bilgi Bankası) 
mahkemesine istinaf kanun yoluna başvurulabilir. ${ }^{57}$ Bölge idare mahkemesi idare veya vergi mahkemesinin vermiş olduğu kararı hukuka uygun bulduğu takdirde istinaf başvurusunun reddine karar verecektir. İstinaf başvurusunun reddine ilişkin karar, IYUK'un 46. maddesi uyarınca mümkünse, Danıştay'da temyiz edilebilecektir. ${ }^{58}$ Bölge idare mahkemesi, idare veya vergi mahkemesinin yenileme başvurusunun reddine ilişkin verdiği kararı hukuka aykırı bulduğu takdirde istinaf başvurusunun kabulü ile ilk derece mahkemesinin kararının kaldırılmasına karar verecektir. IYYUK'un 45/4. maddesi uyarınca bölge idare mahkemesi, işin esası hakkında yeniden bir karar vereceği için yenileme başvurusunun kabulüyle birlikte yeniden yargılamayı da yapacak ve işin esası hakkında yeniden bir karar verecektir. ${ }^{59}$

Yargılamanın yenilenmesi başvurusu, bölge idare mahkemesinin esas hakkında verdiği karara veya İYUK'un 20/A ve 20/B kapsamında verilen bir karara karşı yapılmışsa yenileme başvurusunun reddine ilişkin karara karşı Danıştay'da temyiz yoluna başvurulabilir. ${ }^{60}$

IYYUK'un 45/1. maddesi kapsamında ilk derecede kesin olarak verilen kararlara karş1 yapılan yargılamanın yenilenmesi isteminin reddi kararı da kesin olarak verilecek midir? $\mathrm{Bu}$ kararların da kesin olarak verilmesi halinde bunlara karşı istinaf kanun yolunun kapalı olduğu söylenebilir. Ancak yargılamanın yenilenmesi sebeplerinin dava konusundan ayrı düşünülmesi gerektiği ve yargılamanın yenilenmesi kurumunun varlık amacı göz önüne alındığında; ret kararına karşı olağan kanun yoluna başvurulması gerektiği ileri sürülebilecektir. ${ }^{61}$ Kanaatimizce kanunda ilk derecede kesin olarak verilen kararların öngörülmesindeki amaç, söz konusu kararlara karşı olağan kanun yoluna başvurulmasının önüne geçilerek uyuşmazlığın sürdürülmesini engellemektir. Başka bir ifadeyle söz konusu kararlara karşı -kararın içeriğini oluşturan uyuşmazlığın niteliğine bağlı olarak- olağan kanun yoluna başvurulmasına gerek olmadığ1 yönündeki kabuldür. İlk derecede kesin olarak verilmiş bir karara karşı yapılan yargılamanın yenilenmesi başvurusunun reddine ilişkin kararın içeriğini oluşturan uyuşmazlık, ilk derecede kesin olarak verilen kararın içeriğini oluşturan uyuşmazlıktan farklı olabilir. Şöyle ki; yenileme başvurusunun reddine ilişkin kararın içeriğini oluşturan uyuşmazlık, yenileme sebebinin varlığına, yenileme sebebinin haksızlığına veya başvuru süresine ilişkin olabilir. Bu nedenle yalnızca ilk derecede kesin olarak verilen karar söz konusu olduğu için ona karşı yapılan yenileme başvurusunun reddine ilişkin kararın da kesin olduğu ve ret kararına karşı olağan kanun yoluna başvurulamayacağı söylenemez.

\section{b. Yeniden Yargilama}

Yargılamanın yenilenmesi başvurusunun kabulü halinde mahkeme davaya yeniden bakarak karar verecektir. Yeniden yargılama sonucunda mahkeme önceki kararını verebileceği gibi kısmen veya tamamen farklı bir karar da verebilir. Yargılamanın yenilenmesi üzerine verilen kısmen veya tamamen farklı kararın önceki hükmün yerini alacağı kabul edilmektedir. ${ }^{62}$

Peki yapılacak yeniden yargılama ne gibi hususlar içerecektir? Yeniden yapılacak yargılamaya iliş̧kin olarak IYUK'ta yalnızca duruşma yapılmasına ilişkin hüküm sevk edilmiştir. IYYUK'un 55/4. maddesine göre "Yargılamanın yenilenmesi istemlerinde duruşma yapılması görevli daire veya mahkemenin kararına bağlıdır." Yargılamanın yenilenmesi sebeplerinin bulunup bulunmadığına ilişkin inceleme mahkeme tarafından evrak üzerinden yapılacağı gibi;

\footnotetext{
${ }^{57}$ AKYILMAZ/SEZGINER/KAYA, s.718.

58 “Ankara 13. İdare Mahkemesince verilen (...) karar usul ve hukuka uygun olup yargılamanın yenilenmesi talebinin reddine iliş̧kin kısmına yönelik davacının istinaf isteminin yukarıdaki açıklama ile reddine (...) 2577 sayılı Yasanın değişik 46. maddesi uyarınca kararın tebliğinden itibaren 30 gün içerisinde Danıştay'a temyiz yolu açık olmak üzere (...) karar verildi.” Ankara BİM 2. IDD, 18. 04. 2019, E. 2018/3004 K. 2019/782. (Lexpera)

"Kayseri 2. İdare Mahkemesince verilen (...) kararın; yargılamanın yenilenmesi talebinin reddine ilişkin kısmı hukuka uygun olup kaldırılmasını gerektiren bir durum bulunmadığından bu hususa yönelik davacının istinaf isteminin reddine (...) kararın tebliğinden itibaren 30 gün içinde Danıştay'da temyiz yolu açık olmak üzere (...) karar verildi." Ankara BİM 2. İDD, 10. 07. 2018, E. 2018/1562 K. 2018/1889. (Lexpera)

${ }^{59} \mathrm{Bu}$ durumda bölge idare mahkemesinin yeniden yargılama yapması ve işin esası hakkında yeniden bir karar vermesinin İYUK'un 53/2. maddesine aykırılık teşkil edeceği de ileri sürülemez. Şöyle ki; İYUK'un 53/2. maddesi uyarınca yenileme başvurusu esas kararı veren mahkeme (ilk derece mahkemesi) tarafından karara bağlanmış ve normun içerdiği zorunluluk yerine getirilmiştir. Ayrıca bölge idare mahkemesinin istinaf başvurusunu kabul edip dava dosyasını ilk derece mahkemesine göndereceği durumlar IYUK'un 45/5. maddesinde düzenlenmiş olup yargılamanın yenilenmesi başvurusunun reddi kararının varlığı bu durumlardan hiçbirinin kapsamına girmemektedir.

${ }^{60}$ TANSUĞ, s.128.

${ }^{61}$ TANSUĞ, s. 128 .

${ }^{62}$ GÖZÜBÜYÜK, s.546; YILDIRIM, s.441.
} 
yeniden yargılamanın yapılması esnasında da tarafların duruşma talebi bulunsa dahi mahkeme duruşma talebini kabul etmek zorunda değildir. ${ }^{63}$

IYYUK'ta yeniden yargılama esnasında uygulanacak yargılama usulü kurallarına ilişkin bir sınırlama getirilmediği için IYYU'un ve İYUK'ta kendisine atıf yapılan kanunların ilgili usul kuralları yeniden yapılan yargılamada da uygulama alanı bulacaktır. Ancak bu kuralların, haklılığ mahkeme tarafindan saptanmış yargılamanın yenilenmesi sebepleriyle uyumlu bir biçimde uygulanması gerekmektedir. Misalen bilirkişinin kasten gerçeğe aykırı beyan vermesi sebebiyle yeniden yargılama yapılıyorsa önceki bilirkişi raporu kullanılamayacak yeniden bilirkişiye başvurulması gerekecektir. ${ }^{64}$ Yine, karara esas alınan bir ilam hükmünün kesinleşmiş mahkeme kararıyla bozularak ortadan kaldırılması sebebiyle yeniden yargılama yapılıyorsa ve mahkemenin dayandığı deliller bozulan kararla birlikte geçerliliklerini yitirmişlerse, yeniden delil tespitine gidilmesi gerekir. Yargılamanın yenilenmesi çekinmeye mecbur olan hakimlerin karar vermiş veya karara katılmış olması sebebine dayanıyorsa mahkemenin söz konusu hakimler dışındaki hakimlerden oluşması gerekir. ${ }^{65}$

Yargılamanın yenilenmesi üzerine verilen karara karşı olağan ve olağanüstü kanun yollarına başvurulması mümkündür. ${ }^{66}$ IYYU'un 55/5. maddesi uyarınca IYYUK'un 53. ve 55. maddeleri saklı kalmak üzere İYUK'un diğer hükümlerinin uygulanacağının düzenlenmesi yeniden yargılama sonucunda verilen karara karşı olağan kanun yollarına başvurma imkânı tanır. Ayrıca ne HMK'da ne de IYUK'ta yeniden yargılama üzerine verilen karara karşı tekrardan yargılamanın yenilenmesi yoluna başvurulamayacağına ilişkin bir hüküm bulunmamaktadır. Ancak öğretide aynı sebebe dayanarak yargılamanın yenilenmesi yoluna ikinci kez başvurulamayacağ 1 ifade edilmektedir. Yeniden yargılama sonucunda önceki karardan kısmen veya tamamen farklı bir karar verilmesi halinde verilen karar önceki karardan farklı olduğu için bu karara karşı yargılamanın yenilenmesi yoluna başvurulması ikinci kez başvurma sayılamaz. ${ }^{67}$

\section{SONUÇ}

Yargılamanın yenilenmesi yoluna başvurulabilecek kararların hangileri olduğu konusunda IYUK'ta yapılan temel belirleme, idari yargı mercilerine ilişkin olup bu merciler açısından herhangi bir sınırlama yapılmamıştır. Danıştay, bölge idare mahkemeleri, idare mahkemeleri ve vergi mahkemelerinin kararlarına karşı yargılamanın yenilenmesi yoluna başvurmak mümkündür. Yargılamanın yenilenmesinin medeni usul hukukunda olağanüstü kanun yolu olarak nitelendirilmesi ve IYUK'ta kesin/kesinleşmiş mahkeme kararlarına karşı başvuru yapılabileceğine ilişkin herhangi bir sınırlama bulunmamasına rağmen kesinleşmemiş mahkeme kararlarına karşı olağan kanun yolları olan istinaf ve temyiz imkânlarının varlığı sebebiyle idari yargılama hukukunda da kesin/kesinleşmiş mahkeme kararlarına karşı yargılamanın yenilenmesi yoluna başvurulabileceği kabul edilmiştir.

IYYUK'ta yargılamanın yenilenmesi başvurusunu esas kararı veren mahkemenin karara bağlayacağının ifade edilmiş olmasını, yargılamanın yenilenmesi yoluna başvurulabilecek kararlar açısından bir sınırlama olarak yorumlayan öğreti ve Danıştay; esas karar olmayan başka bir ifadeyle taraflar arasındaki maddi uyuşmazlığı çözmeyen kararlara karşı yargılamanın yenilenmesi yoluna başvurulamayacağını ifade etmektedir. Ancak kanundaki esas karar ifadesinin, esasa ilişkin/esas hakkında karar anlamında kullanılmadığı, uyuşmazlığın asıl yargıcının vermiş olduğu karar başka bir deyişle "asıl karar" anlamında kullanıldığı karşı bir görüş olarak ileri sürülebilir. Yargılamanın yenilenmesinin, hukuki hatalarının ağırlığı sebebiyle hukuk aleminde var olması kabul edilemez bulunan mahkeme kararlarının ortadan kaldırılarak yeniden yargılama yapılmasının sağlanması amacını taşıdığı düşünüldüğünde; taraflar arasındaki maddi

\footnotetext{
${ }^{63}$ YILDIRIM, s.441.; YENICE/ESIN, s.748.

${ }^{64}$ BUDAK, Ali Cem/KARAASLAN, Varol: Medeni Usul Hukuku, Adalet Yayınevi, Ankara 2017, s.386.

65 TANSUĞ, s. 131 vd.

${ }^{66}$ AKYILMAZ/SEZGINER/KAYA, s.718.; KAPLAN, s.469. “2577 sayıl İdari Yargllama Usulü Kanunu'nun 53. maddesinin 1. fikrasinda, yargllamanin yenilenmesi sebepleri sayma yolu ile tek tek belirlenmiş olup, Daire kararında yer verilen sebep ve davacı tarafindan ileri sürülen hususlar, 2577 sayıl Kanun'da sayılan yargılamanın yenilenmesi sebeplerinden hiçbirine uymamaktadır. Bu nedenle, yargllamanin yenilenmesi isteminin kabul edilerek, dava konusu işlemin iptali yolunda verilen Daire kararında hukuka uygunluk görülmemiştir. Açıklanan nedenlerle, davalı idarenin temyiz isteminin kabulüne, Danıştay Sekizinci Dairesinin (...) kararın bozulmasına, (...) karar verildi.” Danıştay İDDK, 23. 03. 2017, E. 2016/910 K. 2017/1355. (Lexpera)

${ }^{67}$ ÇAĞLAYAN, s.487.
} 
uyuşmazlığı çözmeyen birtakım kararlara karşı da yargılamanın yenilenmesi yoluna başvurulabilmesi gerekir. İdari yargıda özellikle iptal davalarında yargılanan, idari işlem olup; idarenin hukuka uygunluğu sağlanmaya çalışılmaktadır. İdari işlemin hukuka uygunluk denetiminden geçmesinin önünde engel oluşturan davanın süreaşımından reddi kararlarına karşı niçin yargılamanın yenilenmesi yoluna başvurulamayacağının cevabını bulmak kolay değildir. Özellikle dava açma süresinin yazılı bildirim tarihinden itibaren başladığı durumlarda idarenin yazılı bildirim tarihine ilişkin olarak hileli davranışlarda bulunmak suretiyle davacının dava açma süresini kaçırmış görünmesine ve dolayısıyla davanın süreaşımından reddine sebebiyet vermesi mümkündür.

2014 yılında idari yargılama usulünde olağan kanun yollarının hukuki rejimi değiştirilmiş ve olağan yargılama usulünden ayrılan özel yargılama usulleri getirilmiştir. Özel yargılama usullerinde olağan kanun yolları da olağan yargılama usulünden farklılaştırılmıştır. Tüm bu değişiklikler yapılırken yargılamanın yenilenmesinin hukuki rejimine dokunulmamıştır. Kanun yollarına ilişkin yapılan temel ayrım, mahkeme kararının kesin olup olmamasına dayandırılmakta ve kesinleşen mahkeme kararlarına karşı yalnızca olağanüstü kanun yollarına başvurma imkânı bulunmaktadır. Bu ayrım, kanun yollarını birbirinden ayrı düşünülemeyen, birbirine sıkı sıkıya bağl1 yollar haline getirmektedir.

Yargılamanın yenilenmesi başvurusunun esas kararı veren mahkemece karara bağlanacağının düzenlenmesi istinaf ve özel yargılama usulüne tabi davalarda temyiz incelemesi sonucu verilecek kararlarda yenileme başvurusunun hangi mahkeme kararına karşı hangi mahkemeye yapılacağı sorusunun sorulmasına yol açmaktadır. Yargılamanın yenilenmesi başvurusunun özel yargılama usulüne tabi davalarda temyiz incelemesi sonucunda Danıştay'ın vermiş olduğu esas hakkındaki karara karşı Danıştay'a yapılması gerektiği sonucuna varıldığında ilk derece mahkemesi olarak Danıştay’ın görevine giren ve özel yargılama usulüne tabi bir davada yargılamanın yenilenmesi başvurusunun reddine ilişkin İDDK kararına karşı başvurulabilecek herhangi bir kanun yolu merciinin bulunmaması sorunuyla karşılaşılmaktadır. Sonuç olarak yargılamanın yenilenmesine başvurunun hukuki rejiminin özel yargılama usulünde olağan kanun yolları da dikkate alınarak yeniden düzenlenmesi gerektiği düşünülmektedir. 


\section{KAYNAKÇA}

AKYILMAZ, Bahtiyar/SEZGINER, Murat/KAYA, Cemil: Türk İdari Yargılama Hukuku, Savaş Yayınevi, Ankara 2019.

ASLAN, Zehreddin/BARLASS, İrfan/BERK, Kahraman/ARAT, Nilay/SAYHAN, Şebnem/BARDAKÇI, Mehmet Akif/GÜMÜŞKAYA, Gamze/KAĞITCIOĞLU, Mutlu/ALTINDAĞ, Halil: Açıklamalı ve İçtihatlı İdari Yargılama Usulü Kanunu, Seçkin Yayınları, Ankara 2019.

BUDAK, Ali Cem/KARAASLAN, Varol: Medeni Usul Hukuku, Adalet Yayınevi, Ankara 2017.

ÇAĞLAYAN, Ramazan: İdari Yargı Kararlarına Karşı Başvuru Yolları (Fransa - Türkiye Mukayeseli Bir Deneme), Seçkin Yayınları, Ankara 2017.

CANDAN, Turgut: Açıklamalı İdari Yargılama Usulü Kanunu, PwC, İstanbul 2015.

DURAN, Lütfi: “İdari Yargı Adlileşti”, İdare Hukuku ve İlimleri Dergisi, 3(1-3), 1982, s.53-83.

EROĞLU, Hamza: İdare Hukuku Dersleri Genel Esaslar, İdari Teşkilat ve İdarenin Denetlenmesi, Sevinç Matbaas1, Ankara 1974.

GÖZÜBÜYÜK, A. Şeref: Yönetsel Yarg1, Turhan Kitabevi, Ankara 2016.

GÖZÜBÜYÜK, A. Şeref/TAN, Turgut: İdare Hukuku C. 2 İdari Yargılama Hukuku, Turhan Kitabevi, Ankara 2016.

KALABALIK, Halil: İdari Yargılama Usulü Hukuku, 14. Baskı, Seçkin Yayıncılık, Ankara 2020.

KAPLAN, Gürsel: İdari Yargılama Hukuku, Ekin Yayınları, Bursa 2016.

KARAHANOĞULLARI, Onur: İdari Yarg1 İdarenin Hukuka Zorlanması (Yarg1 Kararlarına Dayalı Bir İnceleme), Turhan Kitabevi, Ankara 2019.

KARAMAN, Ebru: Karşılaştırmalı Anayasa Yargısında Bireysel Başvuru Yolu, On İki Levha Yayıncılık, İstanbul 2013.

KURU, Baki/ARSLAN, Ramazan/YILMAZ, Ejder: Medeni Usul Hukuku, Yetkin Yayınları, Ankara 2014.

NAMLI, Mert: Türk ve Fransız Medeni Usul Hukukunda Yargılamanın Yenilenmesi, Beta Yayınları, İstanbul 2014.

ODYAKMAZ, Zehra: Türk İdari Yargılama Usulünde Kararlara Karşı Başvuru Yolları, Alfa Yayınları, İstanbul 1993.

ONAR, Sıddık Sami: İdare Hukukunun Umumi Esasları, C. 3, İsmail Akgün Matbaası, İstanbul 1966.

ÖZEKES, Muhammet: Pekcanıtez Usul Medeni Usul Hukuku Cilt III, 15. Baskı, On İki Levha Yayıncılık, İstanbul 2017.

PEKCANITEZ, Hakan/ATALAY, Oğuz/ÖZEKES, Muhammet: Medeni Usul Hukuku, Vedat Kitapç1lık, İstanbul 2017.

TANSUĞ, Çağla: İdari Yargılama Hukukunda Yargılamanın Yenilenmesi, Beta Yayınları, İstanbul 2016.

TEKİNSOY, M. Ayhan: “Danıştay’ın Temyiz İncelemesi Üzerine Verdiği Kararların Uygulanması”, İnönü Üniversitesi Hukuk Fakültesi Dergisi, 5(2), 2014, s.23-50.

TUNCAY, Aydın H./ÖZDEŞ, Orhan/BAŞPINAR, Recep: “İdari Yargılama Usulü”, Yüzyıl Boyunca Danıştay 1868 - 1968, Ankara 1968, s.598-729.

ULUSOY, Ali D.: Yeni Türk İdare Hukuku, Yetkin Yayınları, Ankara 2019.

ÜSTÜN, Gül: “2577 Sayılı İdari Yargılama Usulü Kanununda Öngörülen Yeni Bir Yargılamanın Yenilenmesi Sebebi: Geçici 9. Madde”, Hukuk Araştırmaları Dergisi, 25(1), Haziran 2019, s.15-26.

YAŞAR, Hasan Nuri: İdari Yargı Kararlarının Etkinleştirilmesi Arayışında İdari Yargı İdari Yargıç Yargısal Emir, On İki Levha Yayıncılık, İstanbul 2013.

YENICE, Kazım/ESIN, Yüksel: Açıklamalı - İçtihatlı - Notlu İdari Yargılama Usulü Kanunu, Arısan Matbaacilık, Ankara 1983.

YILDIRIM, Ramazan: "Türk İdari Yargısında Yargılamanın Yenilenmesi”, Prof. Dr. Nuri Çelik'e Armağan, Marmara Üniversitesi Hukuk Fakültesi, C. 1, s.418-447.

Çevrimiçi Kaynaklar

AYM Kararlar Bilgi Bankası: http://www.anayasa.gov.tr/tr/kararlar-bilgi-bankasi/(Erişim Tarihi: 10. 03. 2020)

Danıştay Bilgi Bankası: http://emsal.danistay.uyap.gov.tr/BilgiBankasiIstemciWeb/(Erişim Tarihi: 10. 03. 2020)

Kazancı İçtihat Bilgi Bankası (Kazanc1): http://www.kazanci.com (Erişim Tarihi: 10. 03. 2020)

Legalbank Elektronik Hukuk Bankası (Legalbank): http://legalbank.net (Erişim Tarihi: 10. 03. 2020)

Lexpera Hukuk Bilgi Sistemi (Lexpera): http://www.lexpera.com.tr (Erişim Tarihi: 10. 03. 2020)

Sinerji İçtihat ve Mevzuat Programı (Sinerji): http://www.sinerjimevzuat.com.tr (Erişim Tarihi: 10. 03. 2020)

TBMM Tutanakları: http://www.tbmm.gov.tr/kutuphane/tutanak_sorgu.html (Erişim Tarihi: 10. 03. 2020) 